\title{
Problem Based Learning Teaching Approached in Nutrition Counselling Topic of Nutrition Education Subject by e-learn Computer Assisted Instruction of Undergraduate Nutrition Students at Publich Health Faculty of Andalas University
}

\author{
Denas Symond $^{1 *}$ Nadya Chalida Nur ${ }^{2}$, Putri Aulia $\mathrm{Arza}^{3}$ \\ ${ }^{1,2,3}$ Department of Nutrition, Public Health Faculty of Andalas University, Padang \\ * Corresponding Author. E-mail:denaspdg@gmail.com, Phone:+6281363326808
}

\begin{abstract}
Nutrition Conselling is one of topic of Nutrition Education Subject in third semester undergraduate nutrition students at Faculty of Public Health Univerisity of Andalas. During the learning process, teacher adopted Problem Based Learning approached by e-learn method in teaching and should use interactive mulimedia for student, not only hear, see and memorize concepts that are abstact.

Student are expected to do is not just to remember the fact sothat students have no trouble during the learning process. Teachers are expected to be able to use interactive multimedia to make students active to ask, motivated in learning by utilizing a computer. The use of the computer as a medium of learning known as learning with Computer Assisted Instruction (CAI).

The application of Computer Assisted Instruction (CAI) in teaching process use e-learn is one of the innovation of the learning media display images that are packed in the form of a brief narrative about the animation and the learning is being done, so that it can attract the interest of students. This study aims to adopt the e-learn method as IT-based learning model use problem based learning approached for teachers in teaching and give fun space for student without being limited by space and time.

As of 66 students participates in clasroom action research topic Nutrition Counselling on the subject of Education Nutrition. Problem Based Learning (PBL) approached was developed to provide opportunities for student to teacher to determine problems in the topic of adaptation and evolution.

Aplication of the learning approached of Problem Based Learning in Undergarduate Nutrition Students can (1) enhance student activities (2) increase student activity from the first cycle to the second cycle and the second cyscle to third cycle (3) the respons of students to Problem Based Learning approached are very positive in that students become more active in the discussion.

The results showed that there is an increase in the activity of students actively involved in all learning process from all cycles. The increase in the number of student who are actively in involved in each cycle is of $60 \%$ (40 students/66 students) in the first cycle, $78 \%$ (52 students/66 students) in the second cycle and third and four cycle almost $90 \%$ involve. It can be conclude that Problem Based Learning approached by e-learn method in teaching usefull as interactive mulimedia for student, not only hear, see and memorize concepts that are abstact but come to reality.

AcknowledgementsThanks to LP3M (Institute of Educational Development and Quality Assurance) Andalas University who support research fund and teachers in team teaching who made already this study done and succesfull.
\end{abstract}

Keywords: Development Action Research, Problem Based Learning, I-Learning,Nutrition Education 


\section{INTRODUCTION}

Nutrition Conselling is one of topic of Nutrition Education Subject in third semester undergraduate nutrition students at Faculty of Public Health Univerisity of Andalas.Nutrition Conselling subject aims in order for graduates has academic knowledge, skill of manajerial and communication skill in councelling.Learning process methods adopted before using conventional by lecture in front of class room using panel board and or in focus as media of teaching.

During pandemic Covid19 the learning process should be done by distance learning and create teaching method focus on student center learning by adopted Problem Based Learning technique.Using Problem Based Learning approached by e-learning method in teaching hopefully make interactive mulimedia for student, not only hear, see and memorize concepts that are abstact.

Student are expected to do is not just to remember the fact sothat students have no trouble during the learning process. Teachers are expected to be able to use interactive multimedia to make students active to ask, motivated in learning by utilizing a computer. The use of the computer as a medium of learning known as learning with Computer Assisted Instruction (CAI).

Emphasis on nutrition councelling subject focusing on new learning experince of gaining knowledge and skill of student to do how an student able to do get information, give solution, motivation and keep relation to patient in giving nutrition counselling. This study aims to develop a positive attitude among nutrition students toward using problem base learning by e-learning technique in applying new technical knowledge and skill especially the subject of Nutrition Counselling.

\section{THE METHODS}

Aplication of the learning approached of Problem Based Learning by E-learning as tool of distance learning during pandemic covid19 during 16 cycle teaching divided into 5 steps (1) Problem orientation based on topic (2) Organizied students (3) Collected information by Student (4) Presentation Result (5) Evaluation

The data colelection for this study was administered at the completion of the module subject by obtaining 66 students feedback using a questionnaire.The questionnaire is used as a data collection about participation and behaviour during attending lecture. The guestionaire used a likert scale of 1-5 and was devided into two part. Part one participation include: attending, information collection, communication and analysis. Part two behaviour include group discussion, discipline and domination. The all questionnaire provided data on the overall perception of students towards the 5 steps problem based learning approached in teaching
model.Statistical package for the social sciences (SPSS) version 20 sofware programs was used to analyses the quantitative data. Descriptive statistical analysis was used to determine mean score and percentage and standard deviation.

\section{RESULT AND DISCUSSION}

From the questionaire conducted, students ranked the following in terms of their understanding of the various dynamic learning of gaining knowledge and skill used in the Problem Based Learning techniques to achieve the learning outcome.

The fist step in problem based learning cycle in group organizied, a student explained scenario topic discussed by brain storming. During brainstorming tray make problem tree and explored any question regarding with problem tree. All this problem tree about scenario based reference.The result step one by self questionaire answer and lecture observation as follow

\begin{tabular}{|l|l|c|c|}
\hline No & Indicator & N & Percentage \\
\hline 1 & Introduced idea or concept & 2 & 5 \\
\hline 2 & Answer question & 6 & 15 \\
\hline 3 & Inform/Introduced Problem & 10 & 25 \\
\hline 4 & Giving solution & 22 & 55 \\
\hline & Total in cycle I & 40 & 100 \\
\hline & Number students & 66 & \\
\hline
\end{tabular}

From data bove 40 students participate in lecture by giving variation idea and answering question based on indicator flatform. Ten students involved in introducing problem tree based scenario flatform

The second step made a member of group student organized regularly explained the answering of each question their made. They have 5 group consist of 10-11 members. The result of each group presentation get respond by observation in lecture session, clearly mostly $(80 \%)$ can answer the question based reference they have.

The third session all 5 groups member continued discusssion to prepare pleno session. In this session some actvities were done by student as follows (1) Elaborate idea and problems appear in last session by every student (2) Every student thinks factor afected why happen like that (3) Every student give the answer all question offer by their friend (4) Finally they make conclution.

The result this session based on self questionaire answer and lecture observation as follow

\begin{tabular}{|l|l|c|c|}
\hline No & Indicator & N & Percentage \\
\hline 1 & Introduced idea or concept & 4 & 8 \\
\hline 2 & Answer question & 10 & 19 \\
\hline 3 & Inform/Introduced Problem & 12 & 23 \\
\hline 4 & Giving solution & 26 & 50 \\
\hline & Total in cycle I & 52 & 100 \\
\hline & Number students & 66 & \\
\hline
\end{tabular}

Highest score at the third session in apllying problem based learning technique are highest student know and introduce problems and giving solution. This mean using 
problem based learning technique the student can solve the problem based on problem scenario made. At the end of this session they prepare the pleno session at the next session

The four session is practical and each group present how to be a concellor in giving nutrition education to patient. Due to pandemic Covid19, the practical done by simulation by representative of each groups by distance learning. Group representavie presentation, there are three components we observe and assest (1) content presentation (2) slide appearance (3) number of writing each slide. The result of overall presentation group get satisfaction result.

The fift session is pleno session and all 5 groups come together in panell session and each group present result of their groups.

\section{CONCLUSION}

A problem based learning technique by e-learning during pandemic covid19 approach in teaching creates a dynamic learning for nutrition students. E-learning by implementing Problem Based Learning techniques was carefully selected in this subject to facilitate in accomplishing the learning outcome.In this project by implementing problem base learning technique using elearn, student were able to enhance their critical thinking skill based on the scientific approach.

Overall, it allowed for the development of the students discipline soecific knowledge, gaining new knowledge and skill to simulate critical thinking to solve problem they have.Further studies need to be researched if student do apply their new gain knowledge and skill in real situation to do counselling to patients

\section{REFERENCES}

[1] Amir, Muahamad Taufiq, 2010, Inovasi Pendidikan melalui Problem Based Learning, Jakarta, Kencana

[2] Dimiyati dan Mujiono, 1994 Belajar dan Pembelajaran, Jakarta Proyek Pembinaan dan Peningkatan Mutu Tenaga Kependidikan Dirjen Dikti Depdikbud RI

[3] Sovoi J.M and Hughes AS, 1994 Problem Based Learning as clasroom solution educational leadership

[4] Silberman M.1996 Active Learning 101 Strategies to teach any subject, Allyn and Bacon

[5] UNAND, 2018 Panduan E-learning Universitas Andalas, Padang ICT

[6] Hasamah 2014, Pembelajaran Bauran (Blanded Learning) Jakarta, Pustaka 